\title{
Relationship Between the Attitudes of Pre-School Teacher Candidates Towards Environmental Issues and Their Self- Efficacy Beliefs About Environmental Education
}

\author{
Nagihan TANIK ÖNAL 1 \\ Niğde Ömer Halisdemir University, Niğde \\ TURKEY
}

\begin{abstract}
${ }^{1}$ Assist. Prof.; Niğde Ömer Halisdemir University, Department of Primary Education, Niğde, Turkey, nagihanta [at gmail.com. ORCID: 0000-0002-5926-521X
\end{abstract}

\begin{abstract}
This study aims to determine the self-efficacy beliefs and attitudes of pre-school teacher candidates towards environmental education and to examine the relationship between these two variables. The research was conducted based on an exploratory sequential mixed-methods design. The participants of the study are 114 pre-school teacher candidates studying at a state university in the central Anatolia region during the 2019-2020 academic year. In the study, quantitative data was collected using the attitude scale towards environmental issues, and a self-efficacy scale for environmental education, while qualitative data was collected through semi-structured interviews with 35 teacher candidates. Quantitative data were analyzed in the SPSS program using statistical analyses suitable for research problems. Qualitative data were subjected to content analysis. As a result, it was found that the self-efficacy beliefs and attitudes of pre-school teacher candidates in environmental education were moderate. While these factors do not show a significant difference by gender, they show a significant difference compared to the variables of self-efficacy in taking previous courses related to environmental education and giving a course related to environmental education in the future. In addition, it has been found that there is a positive relationship between self-efficacy beliefs in environmental education and in attitudes towards environmental issues. The results obtained in the interviews are consistent with these results. As a result of the research, recommendations were made such as providing courses related to environmental education at all levels of education; and providing opportunities for pre-school teacher candidates to practice environmental education in the process of their university education.
\end{abstract}

\section{Keywords}

Environmental Education, Self-Efficacy, Environmental Education Self-Efficacy Beliefs, Attitude, Environmental Issues, Preschool Teacher Candidates 
In the information age we are in, advances in technology benefit people by making our lives easier, but on the other hand, they cause some negativity in the lives of individuals (Önal, 2017; Tanık-Önal, Önal \& Çakır, 2020). In this context, it can be stated that one of the biggest problems of the era is environmental problems (Artvinli \& Demir, 2018). In solving environmental problems, the importance and necessity of environmental education is an indisputable fact. According to this fact, it was agreed that the individuals of our age should receive an effective and qualified environmental education (Hovardas \& Korfiatis, 2012; Hungerford, 2010; Negev, Garb, Biller, Sagy \& Tal, 2010). A pro-active approach towards environmental issues, environmental education, and the exhibited measures taken before problems occur is necessary to promote environmental sustainability, ensure individuals take responsibility, enact environmentally conscious and eco-friendly acts, demonstrate environmental knowledge and environmental awareness, and aim to train individuals with a high level of positive attitude (Hsu, 2004; Kıyıcı, Yiğit \& Darçın, 2014). Environmental education is carried out in different disciplines such as science education and geography education, which is a branch of science that studies natural, human and economic events occurring on Earth by associating them with individuals (Roth, 1992). It is important to make environmental education effective.

One of the most important elements of an effective environmental education is, of course, the teachers (Atasoy, 2005). With environmental education, teachers are expected to train as environmentally literate individuals (Knapp \& Barrie, 2001). However, if teachers lack the knowledge, skills and responsibilities necessary to carry out environmental education, they will not be able to carry out a strong environmental education (Plevyak, Bendixen-Noe, Henderson, Roth \& Wilke, 2001). As can be seen from here, there are many factors that affect the ability of teachers to carry out qualified environmental education. One of the most important of these factors is their self-efficacy beliefs (Moseley, Huss \& Utley, 2010). In other words, environmental education self-efficacy beliefs occupy an important place in the point where teachers educate environmentally conscious environmental individuals (Apaydin Timur, 2020).

Self-efficacy is defined as the confidence and belief that individuals have in themselves that they can perform a task. In other words, self-efficacy belief is not the ability of individuals to do a job, but their belief in themselves to do that job. Selfefficacy beliefs determine individuals ' feelings, thoughts, behaviors and motivations (Bandura, 1994). Therefore, self-efficacy beliefs are very effective for individuals to plan and realize their goals and take action (Cass, Wood, Ingram, \& Edwin, 2003). Self-efficacy belief is effective in academic life at all levels, and self-efficacy belief is an important element of every successful behavior (Schunk, 2011). As can be seen from here, individuals ' successes or failures in any business or thoughts about any subject parallel their self-efficacy beliefs. Individuals with high self-efficacy beliefs are persistent and prefer to fight the challenges they face. Individuals ' self-efficacy beliefs also affect the values they impose on the tasks assigned to them and increase their perception of the benefits of that task and therefore their success (Pajares \& 
Valiante, 2001). For teachers, it is stated that teachers with high self-efficacy beliefs are more willing in the teaching process, make more effort in teaching, are more successful and use their teaching programs better (Brouwers \& Tomic, 2000; Friedman \& Kass, 2002). Teachers' high self-efficacy beliefs increase both their own performance and the performance of their students. In studies related to the subject, it was also revealed that the success of teachers with high self-efficacy perception increased, and accordingly, the success of their students also increased (Bandura, 1997; Gardner, 2009; Saracaloğlu \& Yenice, 2009). In the context of environmental education environmental education be able to give effective and qualified teachers, take responsibility, fulfill their tasks successfully and selflessly studies (Aydın, 2008), and in the process to deal with the problems in front of them to provide selfefficacy beliefs are high, it is important that (Uzel, Adıgüzel, Yllmaz \& Gül, 2018).

Another important factor affecting teachers' ability to provide effective environmental education is their attitude to environmental issues. In order for teachers to achieve success over their students, they must first have sufficient environmental knowledge, a positive attitude, demonstrate environmentally friendly behavior and also possess high self-efficacy. In addition, teachers ' attitudes to environmental issues are directly related to the time they will devote to environmental issues in their lessons and the teaching they will perform (Kim \& Fortner, 2006). It can also be said that this will have an impact on the self-efficacy of teachers. It is believed that the willingness and success of a teacher whose selfefficacy increases will also increase in environmental education. In other words, teachers' attitudes towards environmental issues and environmental education selfefficacy beliefs feed each other positively, and as a result, environmental education is expected to be more effective.

In this context, it is seen as important to reveal the attitudes of future teachers to environmental issues, the self-efficacy beliefs of environmental education and the relationship between these two. It is hoped that such a study will provide important data for environmental education and teacher training policies to be given to teacher candidates. Biology, science, geography and classroom teacher candidates (Uzel, Adıgüzel, Yılmaz \& Gül, 2019), biology teacher candidates (Yılmaz \& Çimen, 2008), primary school teacher candidates (Aydın, 2008; Okumuş \& Öztürk, 2019; Özdemir, Aydın \& Vural, 2009; Sarıbaş, Teksöz \& Ertepınar, 2014; Zayimoğlu Öztürk, Öztürk \& Şahin, 2015), primary school and science teacher candidates (Kahyaoğlu, 2011), social studies, primary and preschool teacher candidates (Çetkin, 2019) and environmental education conducted with social studies teacher candidates there are studies to determine self-efficacy beliefs, but there are almost no studies conducted with preschool teacher candidates. (Apaydın Timur, 2020) Therefore, it is believed that the current research will lead to another research in a similar framework and contribute to the field. In addition, the fact that this study was studied with preschool teacher candidates is also an important value because in order to achieve the goals of environmental education, this education should be started as early as possible. This is because individuals' positive feelings, thoughts and behaviors 
towards the environment are acquired in their early years show themselves in their future lives (Artvinli, Aydın \& Terzi, 2019). For this reason, environmental education given in preschool education, which is the first level of formal education, an important place (Şimşekli, 2001).

A similar result was encountered when the relevant field was evaluated in terms of attitude to environmental issues, and no research was found that examined the attitudes of pre-school teacher candidates to environmental issues focused on learning and teaching environmental issues. However, the environmental education that teachers will perform is closely related to their attitude to learning, understanding and teaching these subjects. In addition, determining the attitudes of teacher candidates on environmental issues is important for changing negative attitudes and developing positive attitudes (Saraç \& Kan, 2015). Finally, teacher candidates' attitudes towards learning and teaching environmental issues may be related to their environmental education self-efficacy beliefs. This is a question that needs to be investigated. But there was also no research in the relevant field that examined the relationship of these two important factors with each other.

The sub-problems of this research, which were carried out taking into account all these considerations, are as follows:

1. What is the level of self-efficacy of pre-school teacher candidates about environmental education and their attitudes towards environmental issues?

2. Do the self-efficacy of pre-school teacher candidates for environmental education and their attitudes towards environmental issues show a significant difference in relation to the gender variable?

3. Do the self-efficacy and attitudes of pre-school teacher candidates towards environmental education show a significant difference compared to the variable of whether they have previously taken an environmental course?

4. Do the self-efficacy of pre-school teacher candidates for environmental education and their attitudes towards environmental issues show a significant difference compared to the variable that they feel sufficient to teach a lesson about environmental education in the future?

5. Is there a relationship between the self-efficacy of pre-school teacher candidates for environmental education and their attitude to environmental issues?

6. What are the views of pre-school teacher candidates about their self-efficacy for environmental education?

7. What are the views of pre-school teacher candidates on the relationship between self-efficacy belief in environmental education and attitude to environmental issues? 


\section{Methodology}

\section{Research Design}

This research, conducted to examine the self-efficacy of pre-school teacher candidates about environmental education and their attitudes towards environmental issues, is a mixed-methods research design in which quantitative and qualitative research methods are used together. Mixed-methods research is the combination of qualitative and quantitative methods by researchers in one study or series of successive studies (Creswell, 2003). The current research was conducted based on the descriptive exploratory sequential mixed-methods research design. In this design, quantitative data is collected first, analyzed, and then qualitative data is collected and analyzed to explain quantitative data in more detail and depth (Creswell \& Plano-Clark, 2011). In this direction, survey and correlation designs were used in the quantitative dimension of the existing research, consisting of two dimensions; the case study design was used in the qualitative dimension. In the quantitative dimension of the current research, the survey design was preferred when examining participants' self-efficacy for environmental education and their attitude to environmental issues in terms of various variables.

This design is intended to determine the existing situation related to the research subject by the way it exists (Fraenkel \& Wallen, 2006). In the current study, the correlation design was preferred when examining the relationship between participants' self-efficacy for environmental education and their attitude to environmental issues. This design is intended to reveal the relationship between at least two variables without interfering with the variables (Fraenkel \& Wallen, 2006). In the qualitative dimension of the research, the qualitative research method case study design was used. Case study can be defined as an in-depth analysis of one or more review units (Yin, 2003). In the study, this design was preferred to get and examine the participants' detailed views on the subject.

\section{Participants}

In the quantitative dimension of this study, 114 pre-school teacher candidates who continued their education at a university located in a province located in the Central Anatolia region were studied during the 2019-2020 academic year. Since it is possible to reach all students in the study, the path of sampling was not taken (Gürbüz \& Şahin, 2016). Therefore, this research is a full-count research. Some information about participants is presented in Table 1 :

Table 1

Information About Participants' Personal Characteristics

\begin{tabular}{llcc}
\hline Demographics features & & $\mathbf{f}$ & $\mathbf{\%}$ \\
\hline \multirow{2}{*}{ Gender } & Female & 102 & 89.5 \\
& Male & 12 & 10.5 \\
\hline Taking a course on the environment & Yes & 43 & 37.7 \\
before & No & 71 & 62.3 \\
\hline Feel sufficient to teach a lesson about & Yes & 55 & 48.2 \\
environmental education in the future & No & 59 & 51.8 \\
\hline
\end{tabular}


Tanık Önal, N. (2020). Relationship Between the Attitudes of Pre-School Teacher Candidates....

Total

114

100.0

As shown in Table 1, 89.5\% of the students in the sample were women and $10.5 \%$ were men. The students in the sample were asked, " Have you ever taken a lesson about the environment?" and $37.7 \%$ said they did whereas $62.3 \%$ said they did not. When the participants were asked "Do you feel sufficient to teach a course in environmental education in the future?" $48.2 \%$ said yes and $51.8 \%$ said no.

In the qualitative dimension of the research, a maximum diversity sampling was included in the purposeful sampling methods. In maximum diversity sampling, the goal is to create a relatively small new sample group so that variable, analogous and different situations are formed in itself (Yıldırım \& Şimşek, 2011). In this study, gender, environment and future environmental education in giving a lesson on getting an education, previously self-efficacy to feel the properties that differ among students who volunteered to participate in the research in terms of qualitative research the study group consisted of 35 students.

\section{Data Collection}

Attitude scale on environmental issues. The attitude scale for environmental issues, which is used to study participants' attitudes towards environmental issues, was developed by Saraç and Kan (2015). The scale contains 20 substances of the quintet likert type. It was found that the scale with a three-factor structure explained $59.04 \%$ of the total variance. The first factor is called "positive emotions for learning and teaching environmental issues", the second factor is "negative emotions for learning and teaching environmental issues", and the third factor is "active activities for environmental issues". Cronbach-Alpha reliability coefficient of the scale .74 was found. In the current research framework, the reliability coefficient of this scale applied to 114 students 86 were found.

Environmental education self-efficacy perception scale. In the current study, the Environmental Education self-efficacy perception scale developed by Özdemir, Aydın and Akar Vural (2009) was used to examine the self-efficacy of pre-school teacher candidates for environmental education. The scale, consisting of 15 substances in the likert type of 5, has a four-factor structure. Factors of the scale have been called "academic competence perception", "responsibility perception", "instructional competence perception" and "orientation perception". The FourFactor Structure accounts for $61.80 \%$ of the total variance. Cronbach-Alpha reliability coefficient of the scale.76. In the current research framework, the reliability coefficient of this scale applied to 114 students for the total score .75\%.

Semi-structured interview. Data of the qualitative dimension of the research was collected through semi-structured interviews. In this context, a semi-structured interview form consisting of seven articles was prepared by the researcher to serve the purpose of the research. The form is presented to the opinion of two field experts and a Turkish language expert. Experts approved the use of the interview form and did not recommend any changes. To examine how the substances in the form then it works for interviews, the average time required to determine three issues that may arise during the negotiations to eliminate pre-school teacher with the candidate pre-treatments were carried out. In preliminary applications, it was found that the 
substances contained in the form were clear and smooth, and no changes were made. Before both pre-application and main applications, participants were informed that their credentials would remain confidential and asked for their permission to receive audio recordings. Oral permission was obtained from the participants and the information was given to the participants that the audio recordings would be written and analyzed, that is, the data would be used for a scientific study, keeping the credentials confidential. The interviews were conducted in a classroom at the University where the participants were studying in order to avoid logistical obstacles such as difficulty reaching and wasting time when coming to the interviews. In this way, the negotiations were completed in a twoweek time frame. Some of the articles included in the interview form are:

1. Do you think you know how to teach environmental education when you're a teacher? Do you consider your knowledge as sufficient? Can you explain why?

2. For you, does a teacher's interest in environmental issues affect their belief that they can effectively teach environmental education? Can you explain why you think that?

3. How do you think the fact that a teacher is related or unrelated to environmental issues affects the environmental education they will perform? Can you explain why you think that?

\section{Data Analysis}

Before the data was analyzed, the arithmetic mean, mode, median, skewness Attitude scale and kurtosis values were first looked at to test normality, and then the normality test checked whether the data was normal distribution. Normality test results for the total score of the scales are given in Table 2.

Table 2

Normality Results for The Total Score of The Scales

\begin{tabular}{ccccccc}
\hline & \multicolumn{2}{c}{ Kolmogorov-Smirnov } & \multicolumn{4}{c}{ Shapiro-Wilk } \\
& Statistics & sd & p. & Statistics & sd & p. \\
\hline Self-efficacy scale & .071 & 114 & $.200^{*}$ & .994 & 114 & .907 \\
\hline Attitude scale & .075 & 114 & .159 & .981 & 114 & .114 \\
\hline
\end{tabular}

$* \mathrm{p}<.05$

As can be seen from Table 2, The Sig of both the Shapiro-Wilk test and the Kolmogorov-Smirnov test. Values. Since it is greater than 05, it can be expressed with 95\% confidence that the data is normal distributed. In Table 3, the average score, standard deviation skewness and kurtosis values of both scales are included.

Table 3

Min-Max Points, Average Points, Standard Deviation, Skewness and Kurtosis Values of Scales

\begin{tabular}{lccccccc}
\hline Scale Factors & N & Min. & Max & $\overline{\mathbf{x}}$ & SS & Skewness & Kurtosis \\
\hline Self-efficacy scale (15 item) & 114 & 15.00 & 67.00 & 48.95 & 6.808 & .049 & -.230 \\
Attitude scale (20 item & 114 & 20.00 & 100.00 & 60.87 & 10.011 & .466 & .415 \\
\hline
\end{tabular}

In Table 3, it is seen that the skewness and kurtosis values of the scores obtained by the teacher candidates from the general of both scales are also in the range of $-/+$ 1 . 
The average score of the self-efficacy scale for environmental education, consisting of 15 items, was 48.95, and the average score of the attitude scale to environmental issues, consisting of 20 items, was 60.87 .

Discontinuous answer options were made continuous using the formula number of options-1/number of options to determine the level of participation of pre-school teacher candidates in items included in the scales. Accordingly, the score ranges of this scale, which are of Likert type 5, are shown in Table 4:

Table 4

Range for Average Scores Obtained From Scales

\begin{tabular}{ll}
\hline Likert Type Options & Points range \\
\hline Strongly disagree & $1.00-1.80$ \\
Disagree & $1.81-2.60$ \\
Neither agree nor disagree & $2.61-3.40$ \\
Agree & $3.41-4.20$ \\
Strongly agree & $4.21-5.00$ \\
\hline
\end{tabular}

An interpretation of the results of the average scores obtained from each item of the scale using the ranges specified in Table 4 is presented in the results.

Pearson multiplication moment correlation analysis was used to test whether there was a significant relationship between pre-school teacher candidates' selfefficacy for environmental education and their attitude towards environmental issues. This analysis is a technique that shows whether there is a relationship between variables with normal distribution and the direction of the relationship if there is a relationship. If the coefficient calculated as a result of the analysis is between 0.00-0.30, it is low between the variables; if it is between $0.30-0.70$, it is medium and if it is between $0.70-1.00$, the existence of a high level of relationship can be expressed (Büyüköztürk, 2017).

Qualitative data collected through semi-structured interviews were analyzed by content analysis method. Content analysis can be defined as the process of creating categories, starting with encoding data (Corbin \& Strauss, 2007). Preliminary preparations were made before the data was analyzed. In this context, audio recordings were transcribed to the letter and translated into MS Word documents. Each document was then given a number starting with K1, which refers to the participant $(\mathrm{K})$, and these numbers were also used as codes in direct quotations.

\section{Credibility and Transferability in Case Study}

In order to increase the credibility of the research, efforts were made to extend the time of the researcher's stay in the state in which the data was collected, the necessary time was allocated and prolonged engagement interaction with the participants was provided. In addition, after the audio recordings were translated into the document and analyzed in the study, they were submitted for approval by the participants, confirming that the data in the document consisting of audio recordings and the results resulting from the analysis performed by the researcher fully reflect the participants ' ideas (member check). Finally, another measure taken to increase the credibility of the research was the expert review (peer debriefing). The research has been presented to a critique of an academic specializing in 
qualitative research methods. The expert examined the qualitative research process and the findings reached as a result of the analysis of the data. He reported that there was no problem with the research in expert feedback.

In order to increase the internal validity of the research, quantitative and qualitative data were used together. The combined use of these two methods in a study ensures that complementary findings are achieved and thus the results of the research are stronger (Mays \& Pope, 2000).

In order to ensure confirmability, the audit trail was preferred. In this context, the audio recordings collected in the research were transferred to both the device and the computer and stored. In addition, the procedure and analysis process followed in the research were reflected in the research report in detail and painstakingly. In addition, excerpts from the participants' own statements were presented while the findings were presented to ensure confirmability (Lincoln \& Guba, 1985).

In order to ensure the transferability of the research, a detailed description (thick description) has been taken. In this context, detailed information about the research was given, the findings were presented without comment and direct quotes were given (Lincoln \& Guba, 1985).

\section{Findings}

\section{Results of Descriptive Analysis of The Self-Efficacy Scale for Environmental Education}

In the first study, it was tried to determine the level of self-efficacy of pre-school teacher candidates about environmental education. In this context, the participants ' self-efficacy beliefs scale scores for environmental education were descriptively analyzed. The average (x) and standard deviation (s) values calculated as a result of the analysis are included in Table 5.

Table 5

Descriptive Analysis Results of Substances Included in The Self-Efficacy Scale for Environmental Education

\begin{tabular}{|c|c|c|c|}
\hline Self-Efficacy Scale Articles for Environmental Education & $\mathbf{N}$ & $\overline{\mathbf{x}}$ & $\mathbf{S}$ \\
\hline $\begin{array}{l}\text { 1. I think my conceptual knowledge of the environment is better than many } \\
\text { of my friends. }\end{array}$ & 114 & 3,45 & ,893 \\
\hline $\begin{array}{l}\text { 2. After the environmental education I will give, it will warn my students' } \\
\text { friends who are damaging the environment. }\end{array}$ & 114 & 4,04 & ,728 \\
\hline 3. It's simple for me to do all sorts of experiments with the environment. & 114 & 3,20 & ,864 \\
\hline 4. I know enough to teach environmental concepts effectively. & 114 & 3,18 & ,905 \\
\hline $\begin{array}{l}\text { 5. I believe that I can answer questions about the environment in a } \\
\text { scientific dimension. }\end{array}$ & 114 & 2,86 & ,930 \\
\hline 6. I don't know how to direct students to environmental issues. & 114 & 3,18 & 1,102 \\
\hline 7. I know the method part of many environmental experiments. & 114 & 2,66 & ,930 \\
\hline $\begin{array}{l}\text { 8. The classroom teacher is responsible for the students' achievements in } \\
\text { environmental issues. }\end{array}$ & 114 & 3,28 & 1,093 \\
\hline $\begin{array}{l}\text { 9. I don't know who I can get help with learning about an environmental } \\
\text { issue that I don't understand. }\end{array}$ & 114 & 3,07 & 1,158 \\
\hline
\end{tabular}


Tanık Önal, N. (2020). Relationship Between the Attitudes of Pre-School Teacher Candidates....

\begin{tabular}{|c|c|c|c|}
\hline 10. I believe I am well aware of scientific terms on environmental issues. & 114 & 2,64 & ,988 \\
\hline $\begin{array}{l}\text { 11. After the environmental education I will give, my students develop } \\
\text { environmentally sensitive positive behaviors. }\end{array}$ & 114 & 4,01 & ,793 \\
\hline 12. I don't know how to draw student attention to environmental issues. & 114 & 3,17 & 1,120 \\
\hline $\begin{array}{l}\text { 13. The classroom teacher is responsible for learning about environmental } \\
\text { problems in Turkey. }\end{array}$ & 114 & 3,15 & 1,033 \\
\hline $\begin{array}{l}\text { 14. Classroom teachers are responsible for enabling students to conduct } \\
\text { experiments on environmental issues. }\end{array}$ & 114 & 3,35 & 995 \\
\hline $\begin{array}{l}\text { 15. After the environmental education I will give, my students can } \\
\text { consciously follow environmental events around the world. }\end{array}$ & 114 & 3,72 & ,826 \\
\hline Total & 114 & 3.26 & 454 \\
\hline
\end{tabular}

In Table 5, the overall average of responses of pre-school teacher candidates to substances included in the self-efficacy scale for environmental education was calculated as $x=3.26$. Accordingly, pre-school teacher candidates participating in the study reported opinions in the range of "Neither agree nor disagree" with an average of 3.26. In addition, the substance with the highest average score "will alert my students to environmental harm after the environmental education I will give." while [X=4.04, I strongly agree]; the article with the lowest average score said: "I believe I know the scientific terms on environmental issues well." the article has been $[\mathrm{x}=2.64$, Neither agree nor disagree].

\section{Descriptive Analysis Findings of Attitude Scale on Environmental Issues}

Descriptive analysis was carried out to determine the level at which participants' attitudes towards environmental issues occurred. The average ( $\mathrm{x}$ ) and standard deviation (s) values calculated as a result of the analysis are included in Table 6.

Table 6

Descriptive Analysis Results of Substances Included in The Attitude Scale to Environmental Issues

\begin{tabular}{|c|c|c|c|}
\hline Attitude Scale Articles on Environmental Issues & $\mathbf{N}$ & $\overline{\mathbf{x}}$ & $\mathbf{S}$ \\
\hline 1. I'm very interested in environmental issues. & 114 & 4,02 & ,787 \\
\hline 2. I'm excited to talk about environmental issues. & 114 & 3,69 & 923 \\
\hline 3. I enjoy talking about environmental issues. & 114 & 3,86 & ,881 \\
\hline 4. I feel comfortable talking about environmental issues. & 114 & 3,78 & ,957 \\
\hline $\begin{array}{l}\text { 5. I would like to be a member of journal/journals that publish about } \\
\text { environmental issues. }\end{array}$ & 114 & 3,61 & 1,043 \\
\hline $\begin{array}{l}\text { 6. I'd like to buy it when I see a book or magazine about environmental } \\
\text { issues. }\end{array}$ & 114 & 3,39 & 1,061 \\
\hline $\begin{array}{l}\text { 7. I would like to participate in nature trainings to better understand } \\
\text { environmental issues. }\end{array}$ & 114 & 4,11 & 929 \\
\hline $\begin{array}{l}\text { 8. I would like to be a member of non-governmental organizations that } \\
\text { work on environmental issues. }\end{array}$ & 114 & 4,05 & ,920 \\
\hline 9. I think it's hard to learn concepts about the environment. & 114 & 2.16 & 1,069 \\
\hline 10. I only talk about environmental issues because it's on the program. & 114 & 1.54 & ,923 \\
\hline 11. I get bored talking about environmental issues. & 114 & 1.61 & 927 \\
\hline $\begin{array}{l}\text { 12. I think I'll have a hard time talking about environmental issues in the } \\
\text { future. }\end{array}$ & 114 & 1.94 & 1,024 \\
\hline
\end{tabular}


13. I wouldn't talk about the environment if I could.

14. I find it difficult to learn environmental issues.

15. I get nervous when I talk about environmental issues.

16. I research what I'm interested in about environmental issues in environments such as the internet, books, magazines.

17. I watch videos about environmental issues.

18. I attend seminars or conferences on environmental issues.

19. I chat/discuss environmental issues with my friends, teachers or family.

20. I follow environmental issues from visual, written or social media.

\begin{tabular}{lll}
114 & 1.25 &, 738 \\
114 & 1.53 &, 801 \\
114 & 1.51 &, 844 \\
114 & 4,02 &, 959 \\
114 & 4,04 &, 959 \\
114 & 3,33 & 1,142 \\
114 & 3,68 & 1,075 \\
114 & 3,74 & 1,048 \\
114 & 3.04 & .501 \\
\hline
\end{tabular}

In Table 6, the overall average of responses of pre-school teacher candidates to substances contained in the attitude scale to environmental issues was calculated as $\mathrm{x}=3.04$. This is in the average agree range. In addition, the article with the highest average score in the study "I would like to participate in nature trainings to better understand environmental issues." $[\mathrm{x}=4.11$, Agree $]$ if it is the lowest item", I would not talk about environmental issues if I could." there has been the clause $[x=1.25$, Strongly disagree]

\section{Examination of Pre-School Teacher Candidates' Attitudes Towards}

\section{Environmental Issues and Self-Efficacy Towards Environmental Education in} Terms of Gender

In the study, it was investigated whether the self-efficacy beliefs of pre-school teacher candidates for environmental education and their attitudes towards environmental issues showed significant differences according to gender. Classroom teacher candidates' self-efficacy and attitude scales did not show a normal distribution according to the gender variable, the average of their scores, since non-parametric analysis Mann-Whitney-U-test were analyzed, the results are presented in Table 7.

Table 7

Results of Mann Whitney U Test Analysis Conducted by Gender

\begin{tabular}{llllllll}
\hline & Gender & $\mathbf{n}$ & Mean Rank & $\begin{array}{l}\text { Sum of } \\
\text { Ranks }\end{array}$ & $\mathbf{U}$ & $\mathbf{Z}$ & $\mathbf{P}$ \\
\hline Self-efficacy & Female & 102 & 56.61 & $\begin{array}{l}5774.00 \\
781.00\end{array}$ & 521.00 & -.841 & .400 \\
scale & Male & 12 & 65.08 & 5844.00 & 591.00 & -.194 & .846 \\
\hline Attitude & Female & 102 & 57.29 & 711.00 & & & \\
scale & Male & 12 & 59.25 & & &
\end{tabular}

${ }^{*} \mathrm{p}<.05$

As seen in Table 7, pre-school teacher candidates' self-efficacy and attitude points according to the scale they have received from both of the gender variable is still different in a meaningful way to determine whether the performed non-parametric Mann-Whitney-U test did not show any significant difference between the groups. $[\mathrm{U}=521.00$ and $\mathrm{U}=591.00(\mathrm{p}>.05)]$. 


\section{Examination of Pre-School Teacher Candidates' Attitudes Towards}

\section{Environmental Education in Terms of Self-Efficacy and Environmental Issues}

in Terms of Whether They Have Previously Taken an Environmental-Related

\section{Course}

In the study, it was investigated whether the self-efficacy beliefs and attitudes of pre-school teacher candidates towards environmental education showed a significant difference compared to whether they had previously taken an environmental course. Since the average score of teacher candidates from the selfefficacy and attitude scales was previously normal compared to the variable of whether or not to take a course related to the environment, it was analyzed by the T-test, which is a parametric analysis, and its conclusion is presented in Table 8.

Table 8

Results of T-Test Analysis According to Whether You Have Previously Taken An Environmental Course

\begin{tabular}{cccccccc}
\hline \multicolumn{2}{l}{ Taking an environmental course } & $\mathbf{N}$ & $\overline{\mathbf{x}}$ & SS & sd & $\mathbf{t}$ & P \\
\hline \multirow{2}{*}{ Self-efficacy scale } & Yes & 43 & 51.93 & 5.990 & \multirow{2}{*}{112} & \multirow{2}{*}{3.858} & \multirow{2}{*}{$.000^{*}$} \\
& No & 71 & 47.14 & 6.673 & & & \\
\multirow{2}{*}{ Attitude scale } & Yes & 43 & 63.81 & 11.531 & \multirow{2}{*}{112} & \multirow{2}{*}{2.501} & \multirow{2}{*}{$.014^{*}$} \\
& No & 71 & 59.08 & 8.570 & & & \\
\hline
\end{tabular}

${ }^{*} \mathrm{p}<.05$

As can be seen in Table 8, both the self-efficacy scale of the teacher candidates that make up the sample $(\mathrm{t}=3.858 ; \mathrm{p}<.05)$ as well as the attitude scale $(\mathrm{t}=2.501$; $\mathrm{p}<.05$ ) a significant difference was found in their scores as a result of independent group T-tests performed according to the variable of whether participants had previously taken a course related to the environment. For both scales, the difference was in favor of prospective teachers who said, "Yes, I've taken a lesson about the environment before."

\section{Examination of The Attitudes of Pre-School Teacher Candidates Towards Environmental Education and Environmental Issues in Terms of The Variable of Self-Efficacy in Providing A Course for Environmental Education in The Future}

In the study, it was investigated whether the self-efficacy beliefs and attitudes of pre-school teacher candidates towards environmental education showed a significant difference compared to the variable of self-efficacy in teaching a course towards environmental education in the future. Since the average score of participants from the self-efficacy and attitude scales shows a normal distribution according to the variable of vision enough to give a course for environmental education in the future, it was analyzed by the T-test, which is a parametric analysis, and its conclusion is presented in Table 9. 
Table 9

Results of T-Test Analysis According to The State of Self-Efficacy in Providing A Course for Environmental Education in The Future

\begin{tabular}{cccccccc}
\hline $\begin{array}{l}\text { Ability to teach environmental } \\
\text { education courses }\end{array}$ & N & $\overline{\mathbf{x}}$ & SS & sd & T & P \\
\hline Self-efficacy scale & Yes & 55 & 52.16 & 5.909 & \multirow{2}{*}{112} & 5.454 & $.000^{*}$ \\
\multirow{2}{*}{ Attitude scale } & No & 59 & 45.95 & 6.232 & & & \\
& Yes & 55 & 64.29 & 8.498 & \multirow{2}{*}{112} & 3.719 & $.000^{*}$ \\
\hline
\end{tabular}

${ }^{*} \mathrm{p}<.05$

As can be seen in Table 9, both the self-efficacy scale of the pre-school teacher candidates that make up the sample $(\mathrm{t}=5.454 ; \mathrm{p}<.05)$ as well as the attitude scale $(\mathrm{t}=3.719 ; \mathrm{p}<.05)$ A significant difference was found in the scores of the participants as a result of Independent Group t-tests performed according to the variable of selfefficacy vision to give a course for environmental education in the future. This difference was realized for both scales in favor of candidate teachers who said, "Yes, I consider myself sufficient to teach a lesson about environmental education in the future."

\section{Relationship Between Self-Efficacy Belief in Environmental Education and Attitude Scales on Environmental Issues}

Table 10 shows the relationship between the average score of pre-school teacher candidates from the self-efficacy and attitude scales.

Table 10

Pearson Product Moment Correlation Analysis Results to Determine the Relationship Between Scale Scores

\begin{tabular}{lccc}
\hline Scales & $\mathbf{N}$ & $\boldsymbol{r}$ & $\boldsymbol{P}$ \\
\hline $\begin{array}{l}\text { Self-efficacy scale } \\
\text { Attitude scale }\end{array}$ & 114 & .248 & .008 \\
\hline
\end{tabular}

Looking at Table 10, it is seen that there is a low level of positive correlation between the self-efficacy beliefs in environmental education and attitude scores of pre-school teacher candidates participating in the study [ $(\mathrm{R}=.248 ; \mathrm{p}<.05)$, (Büyüköztürk, 2017)]. Accordingly, it can be stated that the attitudes of pre-school teacher candidates towards environmental issues positively affect their self-efficacy beliefs in environmental education.

\section{Examination of Pre-School Teacher Candidates' Views on Self-Efficacy for Environmental Education and Attitudes Towards Environmental Issues}

Environmental education self-efficacy beliefs of pre-school teacher candidates were examined in detail by qualitative method. In this context, the main purposes of environmental education of teacher candidates; awareness, knowledge, attitude, skills and participation were questioned separately and also examined whether they considered themselves adequate in general.

In the first study, participants were reminded of the main purposes of environmental education and asked about the areas and reasons in which they felt most adequate and inadequate. As a result of the analysis of the data, it was 
understood that the areas in which participants felt least adequate were to inform their students about environmental education (9/35), while the area in which they felt most adequate was to gain a positive attitude towards the environment (28/35). Pre-school teacher candidates explained these views under their own category of characteristics. Accordingly, participants justified it by stating that they do not yet have enough knowledge, but they have a positive attitude towards the environment. Of the participants who express themselves in this way, K21's views are as follows:

\footnotetext{
"No, I don't think I can pass on enough information to my students. Because I don't have enough information. First, it is necessary to inform the candidate teachers. I can do my part in creating environmental awareness, I have this competence, but to raise a fully conscious individual, you also need the support of family and other people. The same goes for environmentally friendly behavior. I love the environment, I love the environment, I have confidence in my students because I also love the environment. I mean, I'm most confident about it. In this direction in the training, we receive." (Female, 2. grade)
}

$\mathrm{K} 2$, who is confident in all areas, said:

"I believe I can create an active desire to participate. Because my student age group likes to act dependent on the teacher and listens to the teacher. I'm confident in other areas as well. I have participated in numerous environmental events so far." expressed in the form.

In the study, participants' perceptions of competence to carry out effective environmental education when they are teachers were also questioned. In this category there are very adequate, partially adequate and inadequate codes available. Nine of the participants reported feeling very adequate, 13 felt partially adequate and 11 felt inadequate. Candidates for teachers who feel adequate have explained this by being interested in environmental issues and knowledgeable about it of the participants who think so, for example, K11 said: "I am sufficient, obviously, because I am enthusiastic and knowledgeable about these issues." expressed his opinion.

Participants who felt partially adequate justified their views under the category of personal development. In this context, participants expressed the need to gain experience in this field, learn more and educate themselves. According to this, K16 "I do not consider myself very adequate in this subject yet, but I believe that I will improve myself in this regard until I become a teacher. Because I need more training, I need some experience". expressed his opinion.

When the opinions of participants who felt inadequate were examined, the opinions of participants were evaluated under the category of lack of selfknowledge. Participants also expressed that this is due to the fact that they have never received environmental education. K33, who thinks this way, "at the moment, I consider myself inadequate because I have never received any environmental training. I need it so much. If I were a teacher now, I don't know what to say or do but love the green." has expressed his opinion with his sentences.

Then, the ideas of the teacher candidates participating in the study about the impact of a teacher's attitudes towards environmental issues on the relationship between environmental education and this were questioned. As a result of the analysis of the data, two categories were created: effective and ineffective. In this context, 33 of the participants, almost all of them, expressed the opinion that the teacher's interest in environmental issues will affect environmental education, his 
self-efficacy belief in this issue and his success in environmental education. The thoughts of $\mathrm{K} 22$ and K29, which are in this view, are explained as follows, respectively.

"It is very effective. One thousand five hundred percent effective. If the teacher tells him about a subject he is interested in, he will enjoy it. He describes the subject he loves in more detail, devotes more time to his class. It also conducts extra-curricular activities. He enjoys himself and the students. This, of course, makes him feel adequate and automatically increases the success of the course."

"It affects a lot, because, as we have seen in educational sciences, a teacher is most interested in whatever subject he or she is personally interested in or considers himself or herself sufficient in that subject, he or she is most focused on that subject during the educational training process. The teacher's indifference to any subject also creates the opposite situation. Of course, if the teacher's awareness of responsibility is developed and professional ethics is established, education will also include environmental issues, even if it is not relevant, but this will not go far beyond the boundaries of the curriculum."

Two participants expressed the opinion that if the teacher is very professional, they may not reflect their subjective judgments in their lesson. K18 " if the teacher is professional, he tells his lesson, although he is not interested in the subject. It would be utopian to expect the teacher to be interested in every subject." explained his thoughts with his sentences.

\section{Conclusion and Discussion}

In order to determine the self-efficacy beliefs and attitudes of preschool teacher candidates towards environmental education and to examine the relationship between these two variables, the results of this study were discussed below.

It can be stated that the environmental education self-efficacy of the pre-school teacher candidates participating in the study is moderate. These finding parallels other studies that found that teacher candidates' perceptions of environmental education self-efficacy were moderate (Kahyaoğlu, 2011; Zayimoğlu Öztürk, Öztürk \& Sahin, 2015). The qualitative findings of the study are in line with the same, and only nine participants in the interviews reported that they considered themselves very sufficient to carry out effective environmental education. Participants who did not consider themselves adequate stated that their knowledge level was low due to their lack of environmental education. From here, it is clear that the self-efficacy of participants in environmental education is at a moderate level due to the fact that participants do not receive environmental education and therefore lack of knowledge.

In addition, teacher candidates included in the self-efficacy scale for environmental education, "after the environmental education I will give, my students will warn their friends who are damaging the environment." I believe I am well aware of the scientific terms on environmental issues," it is the least involved in the article. From here, it is understood that the participants do not have sufficient equipment related to environmental education and lack of knowledge on this issue. The qualitative data of the research is also compatible with this data. As a result of the interviews, it was revealed that the participants did not consider themselves too adequate to provide information about environmental education. Participants who 
felt partially adequate expressed the need to gain experience with environmental education, increase their knowledge and improve themselves.

It can be stated that the pre-school teacher candidates participating in the study have a moderately positive attitude towards environmental issues. A study conducted by Erten (2005) found that the environmental attitudes and environmental knowledge levels of pre-school teacher candidates in general were high, but there were significant deficiencies in some basic environmental knowledge. Uyanık (2016). Elementary math, science, pre-school and primary school teacher candidates have confirmed their knowledge about environmental issues in a study that examined their knowledge and attitudes. Çimen \& Benzer (2019) determined that science and classroom teacher candidates have a high attitude towards a sustainable environment. A similar picture was encountered in the interviews conducted within the scope of the research. Accordingly, it can be stated that pre-school teacher candidates are relatively willing to learn and teach environmental issues. In addition, participants "would like to participate in nature trainings to better understand environmental issues." most of all; some participants said "I wouldn't talk about environmental issues if I could." and this is the least involved in the article. Taking into account the highest and lowest rated substances, it is also understood the willingness of the pre-school teacher candidates participating in the study to address environmental issues. In interviews conducted in the study, participants also stated that they have a positive attitude towards the environment, although they lack information. Therefore, it can be stated that the qualitative and quantitative data of the research overlap.

In the study, it was found that the self-efficacy beliefs of pre-school teacher candidates for environmental education and their attitude to environmental issues did not differ significantly by gender. Related research in the literature also concluded that environmental education self-efficacy of teacher candidates does not show significant differences by gender (Apaydın Timur, 2020; Aydın, 2008; Çetkin, 2019; Okumuş \& Öztürk, 2019; Uzel, Adıgüzel, Yılmaz \& Gül, 2019). Again, there are similar studies that have concluded that attitudes to the environment also do not show significant differences according to gender (Eagles \& Demare, 1999; Kahyaoğlu, Daban \& Yangın, 2008). On the other hand, there is also research showing that teacher candidates' attitudes towards the herd environment (Çimen \& Benzer, 2019) and environmental awareness (Ayeni, 2014) differ in favor of women.

According to another finding reached in the study, participants' self-efficacy for environmental education and their attitude to environmental issues show a significant difference in favor of teacher candidates who previously took environmental courses. Accordingly, it can be stated that it is very important to include courses related to environmental education at all levels of education. This result coincides with the results of similar research in the literature

(Önder, 2015; Özdemir et al., 2009; Uzel, Adıgüzel, Yılmaz \& Gül, 2019). However, unfortunately, most of the teacher candidates do not receive environmental education, and the teacher candidates who receive environmental education also find the education they receive insufficient (Aydın, 2010; Plevyak et al., 2001). On the other hand, there is also research that shows that the environmental education 
self-efficacy of teacher candidates does not significantly differentiate in terms of taking an environmental education course (Zayimoğlu Öztürk, Öztürk \& Sahin, 2015). This may be due to differences in the content of environmental education courses, the instructor who teaches the course, and the way the course is handled. When studies on attitudes to the environment are examined, it is seen that there are studies that are consistent with the findings obtained in this study, as well as studies that reach different results. For example, in the research of Kahyaoğlu, Daban \& Yangin (2008) and Karatekin (2011), it was concluded that the attitudes of teacher candidates towards the environment did not change depending on the state of taking an environmental course at the university.

In the study, it was found that participants' self-efficacy beliefs in environmental education and their attitude to environmental issues showed a significant difference in favor of participants who considered themselves sufficient to teach a course related to environmental education in the future. Accordingly, the effectiveness of teacher candidates' confidence that they can carry out a qualified environmental education was revealed. In addition, this result may be related to higher environmental education self-efficacy and attitudes towards environmental issues of students receiving environmental education. In other words, when teacher candidates take environmental lessons, their belief that they can do environmental education increases, which may increase their environmental education selfefficacy and attitude to environmental issues.

Pre-school teacher candidates to environmental issues self-efficacy and attitudes performed to reveal the relationship between two variables correlation analysis determined that there is a weak relationship between ( $\mathrm{r}=.248)$. Accordingly, as the attitudes of pre-school teacher candidates towards environmental issues increase, it can be said that there is some increase in self-efficacy beliefs. In this study, it was described as an interesting finding that the participants' environmental education self-efficacy beliefs had a positive attitude towards environmental issues at a moderate level, while the relationship was low, creating a positive and high-level relationship expectation between these variables. In the interviews, participants stated that they believe that the attitude of teachers to environmental issues will affect their self-efficacy beliefs in environmental education and even the success of the teacher in this regard. In the literature, there are studies that there is a positive low-level relationship between the self-efficacy perceptions of teacher candidates and their attitude towards the profession (Demirtaş, Cömert \& Özer, 2011).

\section{Suggestions}

Since the study found that the self-efficacy beliefs of preschool teacher candidates for environmental education and their attitude to environmental issues are moderate, it may be recommended to conduct activities aimed at increasing these affective factors in the undergraduate program. In this context, students can participate in activities with the environment, students can be educated in out-ofschool environments, and students can be encouraged to participate in projects related to nature. In addition, in the undergraduate program of pre-school education, as part of the environmental education course, teacher candidates will be 
sent to pre-school institutions to prepare the basis for practicing environmental education.

The affective factors of the pre-school teacher candidates participating in the study show a significant difference compared to the variables of self-efficacy vision for previously taking courses related to environmental education and giving a course related to environmental education in the future. This result once again demonstrates the importance of adding environmental education-related courses to all levels of education, from pre-school to undergraduate. It is clear that in order to do this, it is also necessary to train teachers who can carry out qualified environmental education. Therefore, the lesson to be included in environmental education in different undergraduate programs in the Faculty of Education teacher candidates from first grade up to fourth grade and providing the possibility of their application of environmental education activities they perform is a way to create a portfolio file. In addition, the University and pre-education levels and environmental education content and also providing information on natural disasters, aimed to create sensitivity towards nature, talking about the importance of nature protection and with the content on courses such as geography of the area, regardless of the placement of education programs may also be useful.

Another conclusion reached in the study shows a positive weak relationship between the self-efficacy beliefs of pre-school teacher candidates in environmental education and their attitude to environmental issues. In light of this result, it may be suggested that candidate teachers learn and practice different environmental education activities during these practices in order to increase their attitude towards environmental issues and to increase their self-efficacy beliefs.

In future research, it may be recommended to conduct similar studies targeting preschool teacher candidates with different and wider samples, perhaps even throughout Turkey. Pre-school teachers and other teacher candidates, especially in geography, science, social studies, and elementary school other teachers who played an active role in environmental education as teacher candidates with relevant educational policies and comparative studies will provide important data for the literature to be made.

\section{References}

Apaydın Timur, S. (2020). Study of self-efficacy levels of social studies teachers in the field of environmental education. Master Thesis, Aksaray University Social Sciences Institute, Aksaray. Retrieved from https://tez.yok.gov.tr/UlusalTezMerkezi /TezGoster?key=Eb5EkakJlp3olBdo_wNEGWB_kcc07kqSzvbQtE6MfSAPTFUe5k6Hp 33dwgZqonYN

Artvinli, E., \& Demir, Z. M. (2018). A study of developing an environmental attitude scale for primary school students. Journal of Education in Science, Environment and Health (JESEH), 4(1), 32-45. DOI: 10.21891/jeseh.387478

Artvinli, E., Aydın, R., \& Terzi, İ. (2019). Environmental attitude levels of primary teachers' candidates. Osmangazi Journal of Educational Research, 6(2), 62-78. Retrieved from https://ojer.ogu.edu.tr/Storage/OsmangaziJournalOfEducationalResearch/Uploads /OJER-V6-N2-1(1).pdf

Atasoy, E. (2005). Environmantal education: A study for elementary school students' environmental attitude and knowledge. Doctoral Thesis, UludaĞ University Social 
Sciences Institute, Bursa. Retrieved from https://tez.yok.gov.tr/UlusalTezMerkezi /TezGoster?key=L8ilcwn9ZRRc_YMKxXW1oevSBpFHvAVWWLSAIZ5F7hoZsXFK0yX MXvv1LnsE6uP

Aydın, F. (2010). Geography teacher candidates' views about environment problems and environment education (Gazi University Case). International Online Journal of Educational Sciences, 2(3), 818-839. Retrieved from https://iojes.net/?mod= tammetin\&makaleadi=\&makaleurl=IOJES_256.pdf\&key=41343

Aydın, N. (2008). Influence of class level, seniority and value orientation on self-efficacy beliefs through environmental education of class teachers and prospective teachers. Master Thesis, Adnan Menderes University Social Sciences Institute, Aydın. Retrieved from https://tez.yok.gov.tr/UlusalTezMerkezi/TezGoster?key=wBmNpkQC9Nhi90NLW7 E7-dlySQW9EIK0_K2MXk7RRFBVx0on303_RtEAp-wFBYTh

Ayeni, 0.0. (2014). The influence of socio-demographic factors on environmental education. Awareness of first year students at the Cape Peninsula University of Technology South Africa. The international Journal of science in Society, 5(2), 1-8. DOI:10.18848/18366236/CGP/v05i02/51418

Bandura, A. (1994). Self-efficacy. In V. S. Ramachaudran (Ed.), Encyclopedia of human behavior Vol. 4, 71-81. New York: Academic Press. (Reprinted in H. Friedman [Ed.], Encyclopedia of mental health. San Diego: Academic Press, 1998).

Bandura, A. (1997). Self-efficacy: The exercise of control. New York: Freenman and Company.

Brouwers, A., \& Tomic, W. (2000). A longitudinal study of teacher burnout and perceived self-efficacy in classroom management. Teaching and Teacher Education, 16, 239-253. Retrieved from https://core.ac.uk/download/pdf/55534212.pdf

Büyüköztürk, Ş. (2017). Data analysis for social sciences. Ankara: Pegem Academy Publishing.

Cass, D., Wood, C., Ingram, M., \& Edwin, L. (2003). Career development interventions academic self-efficecy and motivation: A Pilot Study. National Research Center for Career a Technical Education University of Minnesto. Retrieved from https://files.eric.ed.gov/fulltext/ED480312.pdf

Corbin, J., \& Strauss, A. (2007). Basics of qualitative research: Techniques and procedures for developing grounded theory. Thousand Oaks, CA: Sage.

Creswell, J. W. (2003). Research design: Qualitative, quantitative and mixed methods approaches. California: Sage Publications

Creswell, J. W., \& Plano Clark, V. L. (2011). Designing and conducting mixed methods research. Thousand Oaks, CA: Sage.

Çetkin, E. (2019). Determination of education faculty students on self-efficacy beliefs about environmental education. Master Thesis, Afyon Kocatepe University Social Sciences Institute, Afyon. Retrieved from https://tez.yok.gov.tr/UlusalTezMerkezi /TezGoster?key=FgmkGchPKo23qQqBeqzVZnWxHbSMK_WGhFjqiWkWOCv5a9Gtb 4hN8J8ufHOJYfv

Çimen, H., \& Benzer, S. (2019). Examination of science and classroom teacher candidates' attitudes towards sustainable environment. Insan \& Insan, 6(21), 525-542. DOI: 10.29224/insanveinsan.475471

Demirtaş, H., Cömert, M., \& Özer, N. (2011). Pre-service teachers' self-efficacy beliefs and attitudes towards profession. Education and Science, 36(159), 96-111. Retrieved from http://egitimvebilim.ted.org.tr/index.php/EB/article/view/278/241 
Eagles, P. F. J., \& Demare, R. (1999). Factors influencing children's environmental attitudes. Journal of Environmental Education, 30(4), 33-37. Retrieved from https://www.researchgate.net/publication/271994465_Factors_Influencing_Childr en's_Environmental_Attitudes

Erten, S. (2005). Investigation of preservice preschool teachers' behaviors related to environmental awareness. Hacettepe University Journal of Education, 28, 91-100. Retrieved from http://efdergi.hacettepe.edu.tr/yonetim/icerik/makaleler/774published.pdf

Fraenkel, J. R., \& Wallen, N. E. (2006). How to design and evaluate research in education (6th ed.). New York, NY: McGraw-Hill.

Friedman, I.A., \& Kass, E. (2002). Teacher self-efficacy: A classroom-organization conceptualization. Teaching and Teacher Education, 18, 675-686. DOI: 10.1016/S0742-051X(02)00027-6

Gardner, C. C. (2009). Self-efficacy in environmental education: Experiences of elementary education preservice teachers. Doctoral Dissertation, University of South Carolina. Retrieved from https://ui.adsabs.harvard.edu/abs/2009PhDT........36G/abstract

Gürbüz, S., \& Şahin, F. (2016). Research methods in social sciences: Philosophy, method, analysis. Ankara: Seçkin Publishing.

Hovardas, T., \& Korfiatis, K. (2012). Effects of an environmental education course on consensus estimates for pro-environmental intentions. Environment and Behavior, 44(6) 760-784. DOI: 10.1177/0013916511407308

Hsu, S. J. (2004). The effects of an environmental education program on responsible environmental behavior and associated environmental literacy variables in Taiwanese college students. The Journal of Environmental Education, 35(2), 37-48. DOI: $10.3200 /$ JOEE.35.2.37-48

Hungerford H. R. (2010). Environmental Education (EE) for the 21st century: Where have we been? Where are we now? Where are we headed? The Journal of Environmental Education, 41(1), 1-6. DOI: 10.1080/00958960903206773

Kahyaoğlu, M. (2011). Relationship between the self-efficacy beliefs towards environmental education and the learning styles of pre-service teachers. Journal of Educational Sciences Research, 1(2), 67-82. Retrieved from https://dergipark.org.tr/tr/ download/article-file/696393

Kahyaoğlu, M., Daban, Ş., \& Yangın, S. (2008). Attitudes of primary candidate teachers about environmental. Dicle University Ziya Gökalp Journal of Education, 11, 42-52. Retrieved from http://www.dergipark.org.tr/tr/download/article-file/787154

Karatekin, K. (2011). The determination of environmental literacy levels of pre-service teachers of social studies. Doctoral Thesis, Gazi University Education Sciences Institute, Ankara. Retrieved from https://tez.yok.gov.tr/UlusalTezMerkezi /TezGoster?key=zD1B0cW7zVr3VcnZjitVXh47KNOFWwDl0UwJNbcqmcsPFaaTM_o yATgTjV-6axu

Kıyıcı, F. B., Yiğit, E. A., \& Darçın, E. S. (2014). Investigation of pre-service teacher's opinion and environmental literacy level change with nature education. Trakya University Journal of Education, 4(1), 17-27. Retrieved from https://dergipark.org.tr /tr/download/article-file/200325 
Kim, C., \& Fortner, R. W. (2006). Issue-specific barriers to addressing environmental issues in the classroom: an exploratory study. The Journal of Environmental Education, 37(3), 15-22. DOI: 10.3200/JOEE.37.3.15-22

Knapp, D. H., \& Barrie, E. (2001). Content evaluation of an environmental science field trip. Journal of Science Education and Technology, 10(4), 351-357. Retrieved from https://link.springer.com/article/10.1023/A:1012247203157

Lincoln, S. Y., \& Guba, E. G. (1985). Naturalistic inquiry. Thousand Oaks, CA: Sage

Mays, N., \& Pope, C. (2000). Qualitative research in health care, assessing quality in qualitative research. $B M$ J, 320, 50-52. DOI: $10.1136 / \mathrm{bmj} .320 .7226 .50$

Moseley, C., Huss, J., \& Utley, J. (2010). Assessing K-12 teachers' personal environmental education teaching efficacy and outcome expectancy. Applied Environmental Education and Communication, 9(1), 5-17. DOI: 10.1080/15330150903566398

Negev, M., Garb, Y., Biller, R., Sagy, G., \& Tal, A. (2010). Environmental problems, causes, and solutions: An open question. The Journal of Environmental Education, 41(2), 101-115. DOI: $10.1080 / 00958960903295258$

Okumuş, S. \& Öztürk, B. (2019). Investigating of preservice elementary teachers' environmental self-efficacy perceptions in terms of various variables. E-Kafkas ournal of Educational Research, 6(2), 9-18. Retrieved from https://dergipark.org.tr/tr/download/article-file/817649

Önal, N. (2017). Use of interactive whiteboard in the mathematics classroom: Students' perceptions within the framework of the Technology Acceptance Model. International Journal of Instruction, 10(4), 67-86. 6. DOI: 10.12973/iji.2017.1045a

Özdemir, A., Aydın, N., \& Akar Vural, R. (2009). A scale development study on self-efficacy beliefs through environmental education. Journal of Dokuz Eylül University Buca Education Faculty, 26, 1-8. Retrieved from https://dergipark.org.tr/tr /pub/deubefd/issue/25438/268408

Pajares, F., \& Valiante, G. (2001). Influence of self-efficacy on elementary students' writing. Journal of Educational Research, 90, 353-360. DOI: 10.1080/00220671.1997.10544593

Plevyak, L. H., Bendixen-Noe, M., Henderson, J., Roth, R. E., \& Wilke. R. (2001). Level of teacher preparation and implementation of EE: Mandated and non, mandated EE teacher preparation states. The Journal of Environmental Education, 32(2), 28-36. DOI: $10.1080 / 00958960109599135$

Roth, C. E. (1992). Environmental literacy: Its roots, evolution and directions in the 1990s.

Columbus, OH: ERIC/SMEAC Information Reference Center. Retrieved from https://files.eric.ed.gov/fulltext/ED348235.pdf

Saracaloğlu, A. S., \& Yenice, N. (2009). Investigating the self-efficacy beliefs of science and elementary teachers with respect to some variables. Journal of Theory and Practice in Education, 5(2), 244- 260. Retrieved from https://dergipark.org.tr/en/ download/article-file/63234

Saraç, E., \& Kan, A. (2015). The validity and reliability analysis of the attitude scale on the environmental issues for the prospective teachers. Journal of Research in Education and Teaching, 4(2), 142-150. Retrieved from http://www.jret.org/FileUpload/ ks281142/File/14...esra_sarac.pdf 
Sarıbaş, D., Teksöz, G., \& Ertepınar, H. (2014). The relationship between environmental literacy and self-efficacy beliefs toward environmental education. Procedia-Social and Behavioral Sciences, 116, 3664-3668. DOI: 10.1016/j.sbspro.2014.01.820

Schunk, D. H. (2011). Learning theories: An educational perspective. Inc: Pearson Education.

Şimşekli, Y. (2001). The evolution of the activities done in the schools which have been chosen for the project of "Applied Environmental Training" in Bursa on the terms of the contribution of the school administrator and the charged teachers. Uludag University Journal of Education, 14(1), 73-82. Retrieved from https://dergipark.org.tr/tr/download/article-file/153171

Tanık Önal, N., Önal, N., \& Çakır, H. (2020). An investigation of cyberbullying and cybervictimization of mathematics and science pre-service teachers. Malaysian Online Journal of Educational Technology, 8(4), 23-34. DOI: 10.17220/mojet.2020.04.002

Uyanık, G. (2016). Examining of attitudes and knowledge levels towards environmental problems of candidate teachers. Online Science Education Journal, 1(1), 30-41. Retrieved from https://dergipark.org.tr/tr/download/article-file/229376

Uzel, N., Adıgüzel, M., Yılmaz, M., \& Gül, A (2018). The effect of different variables on preservice teachers' perceptions of self-efficacy on environmental education. Erzincan University Journal of Education, 21(3), 93-107. DOI: 10.17556/erziefd.475408

Yıldırım, A., \& Şimşek, H. (2011). Qualitative research methods in the social sciences. Ankara: Seckin Publishing.

Yılmaz, M., \& Çimen, O. (2008). Self-efficiency belief levels of biology education of master students without thesis in biology education. Yüzüncü Yll University Journal of Education, 5(1), 20-29. Retrieved from https://dergipark.org.tr/tr/download /article-file/146322

Yin, R.K. (2003). Case study research: Design and methods (3rd Edition). Sage: Thousand Oaks.

Zayimoğlu Öztürk, F., Öztürk, T., \& Şahin, A. (2015). Examination of environmental education self-efficacy perceptions of classroom teacher candidates. Amasya University Journal of Education Faculty, 4(2), 293-311.

Nagihan TANIK ÖNAL is an Assistant Professor of Primary Education at Nigde Omer Halisdemir University, Turkey. In 2009, she graduated from Erciyes University at Science Education. She completed her master's and doctoral studies at the same university. She worked as a research assistant at Erciyes University until 2018. She is currently working at Niğde Ömer Halisdemir University. Her current research interests include environmental education, science education for gifted children, and technology integration. 